\title{
Basque Primary Adpositions from a Clausal Perspective*
}

\author{
Ricardo Etxepare \\ IKER (UMR5478), CNRS \\ r.etxepare@iker.cnrs.fr
}

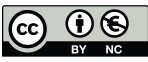

Received: July 21, 2013

Accepted: October 1, 2013

\begin{abstract}
This paper has as its aim to account for an intriguing asymmetry in the domain of primary adpositions in Basque, whereby locatives seem to take a DP ground, whereas the rest of the spatial affixes require a bare nominal ground. I argue that the purported determiner heading the complement of the locative suffix is actually an allomorph of the ergative suffix, and I provide an explanation for why an independent case marker should occur precisely in locative adpositional phrases in Basque, but not in the rest of spatial cases. This explanation requires in turn reconsidering much of the well-established syntactic conclusions on which the traditional analysis of adpositional phrases in Basque rests. In this process, I develop the idea, first suggested by Koopman (2000), that adpositional phrases should be analyzed in close parallelism to the syntax of clauses. Micro-syntactic differences across dialects provide some of the crucial evidence for the proposal.
\end{abstract}

Keywords: adpositions; locatives; ergative; spatial nouns; nominal ellipsis; axial parts; ground; Basque.

\section{Table of Contents}

\section{Introduction 6. Adding Path}

2. On the presence of a determiner

7. A tentative extension of the analysis:

3. More on the syntactic status of - $a$ -

4. Locational nouns in Basque

5. Inessives and elision Persons and things

\section{Summary \\ References}

* I would like to acknowledge financial support from the projects Ministerio de Ciencia e Innovación, FFI2011-29218, (INTERSYNSEM), and Ministerio de Economía y Competitividad FFI201126906, as well as to the network Basquedisyn (supported by the Basque Government) and the UFI UPV/EHU UFI11/14. I am thankful to an anonymous reviewer for a very rich review of the draft, as well as to the audience of the 2011 Colloquium on Generative Grammar, held in Barcelona, and to the research colleagues at the lab IKER (UMR5478) in Bayonne, for repeated input along the years. All errors are mine. 


\section{Introduction}

Basque has three simple or primary adpositions, encoding location (inessive), path (allative) and source (ablative) (Hualde 2002; Trask 2003; De Rijk 2008). A long standing puzzle in the domain of primary adpositions in Basque is the fact that whereas inessives seem to take DP complements (1a), the complements of allatives and ablatives must be bare, even if the spatial ground is interpreted as a definite:

(1) a. mendi-a-n mountain-D-INESS 'in the mountain' b. mendi-(*a)-ra mountain-D-ALL

'to the mountain' c. mendi-(*a)-tik mountain-D-ABL 'from the mountain'

The concrete formulation of the asymmetry between (1a) on the one hand, and $(1 b, c)$ on the other, capitalizes on the existence of (2), an ordinary definite DP. This definite DP is made out of the combination of a noun and the affixal determiner $-a$. (2) is identical to the complement of the inessive suffix $-n$ in (1a).

(2) mendi-a

mountain-D

'the mountain'

This asymmetry raises several questions when placed against the background of recent cartographic approaches to the structure of adpositional phrases. As shown by an increasing amount of cartographic work, in complex directional postpositions a Path feature seems to select the Place feature (see Koopman 2000; Kracht 2002; Svenonius 2006; Pantcheva 2008, 2009; Caha 2009; Riemsdijk and Huygbrets 2007). The complex structure in (3) predicts languages showing adposition stacking, a possibility that seems to be independently attested (see Pantcheva 2008, 2010, 2011). Under something like the Mirror Principle (Baker 1985), stacking phenomena constitute independent evidence for the feature hierarchies proposed in cartographic studies. Thus, in cases of adposition stacking, it is typically the locative morpheme that appears closer to the root than the allative one, as in Tsez (4), and when this type of stacking targets allatives and ablatives, it looks as if the allative is closer to the root than the ablative, as in Quechua (5) (data from Pantcheva 2011: 46-47):

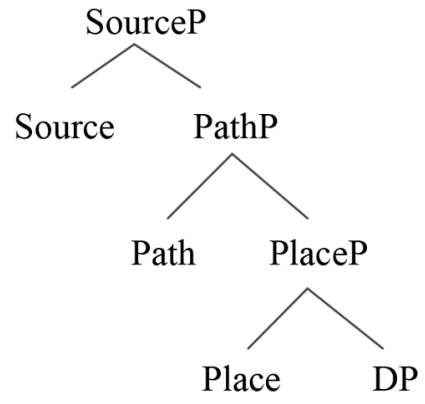


(4)
a. besuro-xo
fish-at
'at the fish'

(5) b. besuro-xo-r
fish-at-to
'to the fish'

b. Utavalu-manda shamu-ni.

Otavalo-ABL come-1SG

'I come from Otavalo.'
Tsez

Quechua
Otavalo-ALL go-1sG

'I go to Otavalo.'

Selective lexicalization of the relevant features in verb framing configurations also provide evidence in favour of the underlying structure in (2) (see Svenonius and Son 2008), as do entailment relations between different primary adpositions (Jackendoff 1983), and the paradigmatic distribution of spatial declension affixes (Kracht 2002). If cartographic hierarchies are correct it is unclear why the addition of a Path feature on top of Place should cause the disappearance of the article, if $-a$ in the locative is the ordinary Basque article $-a$ that you find in (2). Whatever the relevant relation, it goes beyond the local domain defined by the inessive and its nominal complement.

Following earlier work by Jacobsen (1977), De Rijk (1981) and Lakarra (2005), I will try to show that the purported article in (1a) is not the ordinary article in (2), but a case marker historically related to the ergative case suffix $-k$, and that the analysis of the asymmetries in (1a-c) invites a view of adpositional structures that approaches them to clauses, as suggested in seminal work by Koopman (2000). This paper makes the following related claims: first, that locative phrases in general can be binominal, optionally including a silent noun meaning PLACE (as in Kayne 2005; Botwinik-Roten 2004; Leu 2010; Terzi 2010, among others), but may also involve silent PERSON and THING (for the latter see also Kayne 2005). Then, binominal constructions impose certain demands case-wise, and may force the presence of extra case-licensing heads, reflected in the asymmetry in (1a-c) and others. Finally, I will argue, on the footsteps of a large body of work, that Path adpositions are featurally and syntactically complex. The complexity of Path adpositions is not immediately evident in Basque as a result of lexicalization rules that affect complex chunks of structure. In the spirit of the nanosyntax project (see Caha 2009; Starke 2009, among others), I will suggest that lexicalization of featurally complex adpositions targets phrasal syntactic objects.

\section{On the presence of a determiner}

Since Jacobsen (1977), it has been pointed out that the bound sequence -an presents the following phonological property, unexpected under the view that -an represents the sequence $D$-inessive postposition. This particular phonological property consists of an obligatory epenthetic vowel when the stem ends in a consonant:

(6) b. lur-e-an earth-EPENTH-SUFFIX 'in the earth' 
There are two aspects to consider regarding the special status of this epenthetic vowel: the first one, raised by Jacobsen, is that the epenthetic vowel seems to target the wrong morphological boundary if a determiner is assumed. Assuming a morphological representation for case-marked DPs in the following terms:

(7) $\left[_{D P} \mathrm{NP}+\right.$ Det]-Declension Suffix (cf. etxe-a-n 'in the house')

It seems as if the epenthetic vowel targets the boundary that separates the stem and the article:

(8) a. [ Stem $_{\text {Consonant }}+$ epenthetic vowel + Det]-Declension Suffix

b. lur-e-an

earth-EPENTH-SUFFIX

But no such phenomenon is attested in ordinary DPs. Consider in this regard $(9 a, b)$ :
a. lur-a
earth-D
b *lur-e-a
earth-EPENTH-D
'the earth'
'the earth'

As shown in (9b), the epenthetic vowel cannot follow a consonant ending stem before the determiner. If the sequence -an is analysed as Det-iness, it is not clear why an epenthetic vowel is required.

The second aspect that makes the epenthetic vowel special is the fact that it does not obey the usual phonological distribution of epenthetic vowels in Basque. Epenthetic vowels are required in Basque to break the sequence of two consonants in the context of morphological boundaries. This is the case for instance in the rest of the sequences of stem-primary adposition. Both the allative and the ablative suffixes start with a consonant, and an epenthetic vowel is required when the stem they attach to ends with another one:
(10) a. lur-*(e)-ra
earth-EPENTH-ALL
b. lur-*(e)-tik
'to the earth'
earth-EPENTH-ABL
'from the earth'

The morphophonological process illustrated in $(10 a, b)$ is on the other hand, habitual in other morphological boundaries involving potential sequences of consonants. Thus, an epenthetic vowel is required for instance in sequences of stemadnominal suffix, when the stem ends in a consonant. The epenthesis is (morpho) phonologically conditioned: it is blocked if the relevant boundaries do not add up to a sequence of consonants:
(11) a. etxe-ko
b. lur-*(e)-ko
home-ADN
earth-EPENTH-ADN
'of home'
'Of the earth' 
The epenthetic vowel that obligatorily arises in the inessive is peculiar from this point of view too: the suffix starts with a vowel - $a$ (what we called «the determiner») but nevertheless requires an epenthetic vowel. The epenthetic vowel is thus unexpected both from a morphological point of view (the wrong boundaries seem to be targeted) and a phonological point of view (no phonological motivation).

We may add to this the fact that the $-a$ of inessive phrases does not feed other morphophonological phenomena that target $\mathrm{D}$ across dialects. An illustrative case is provided by the dissimilation phenomenon arising in Biscayan when the article $-a$ attaches to a stem that itself ends in $-a$ (12a). This dissimilation process affects the stem final $-a$. Dissimilation does not arise in inessives (12b) (apud Martinez Areta 2010): ${ }^{1}$

(12) a. alaba 'daughter' $+-a \rightarrow$ alabea 'the daughter'

b. gona 'skirt' $+-a n \rightarrow$ gonan 'in the skirt' / *gonean

\subsection{A little historical morphosyntax}

Jacobsen provides an account of the epenthetic vowel, that he views as the historical residue of an underlying sequence of two distinct morphemes, none of which is the determiner: the first one would involve a consonant, unrealized in our time, the second one being the inessive, as in (13). The underlying consonant in (13) accounts for the presence of an obligatory epenthetic vowel. What looks like the determiner $-a$ is in fact part of another morpheme, which starts with a (nowadays unrealized) consonant. This underlying consonant (represented as $\mathrm{C}$ below) triggered the presence of the epenthetic vowel. The actual epenthesis is a historical residue of this state of affairs (an internally conditioned allomorph, in the sense of Mascaró 2007; see below).

(13) $\operatorname{lur}+\mathrm{Ca}+-\mathrm{n}$

De Rijk (1981) has suggested that the unrealized consonant in (13) corresponds to the velar consonant of the suffix $-g a$. This suffix marks animate grounds in Basque and precedes the inessive:

(14) a. *Aitor-en

Aitor-INESS 'in Aitor' b. Aitor-en-ga-n

Aitor-GEN-SUFFIX-INESS 'in Aitor'

The reason why the consonant is not realized with non-animate grounds is due to a historical phonological rule of weakening that applied to voiced consonants

1. As a reviewer notes, dissimilation processes are operative in some dialects even in inessives. For instance, in Lekeitio Basque, a rule of vowel assimilation can target the vowel of inessive after dissimilation: itxaso- $a-n$ 'in the sea' > itxasu- $a-n>i$ txasu- $u-n$, likewise etxe- $a-n$ 'in the house' $>$ etxi-a-n > etxi-i-n (Elordieta $1997 \mathrm{a}, \mathrm{b})$. But crucially, elixa-a-n 'in the church' gives elixan, not *elixin, and gona-a-n yields gonan, not * gonin . 
between vowels. The reason why the consonant is overtly realized in (14) follows from the fact that animate grounds, besides undergoing locative declension are obligatorily case-marked by a genitive case-suffix that ends in a consonant. This way, the locative declension suffix does not find itself surrounded by vowels, and the structural description for the weakening rule does not arise. ${ }^{2}$ In other words, $-a$ and $-g a$ are historically related allomorphs in the context of inessive phrases. As shown by Lakarra (2005), - $g a$ - is actually an allomorph of the ergative suffix, realized as a voiceless velar $-k$ in final position: ${ }^{3}$

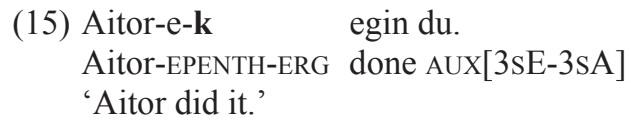

The affix - $g a$ - has thus resulted in two different allomorphs: $-a$ - between vowels (weakening) and $-k$ in final position (loss of voicing). If we stand on the footsteps of De Rijk, we may conclude that - $a$ in the inessive phrases is a case marker historically related to the ergative. ${ }^{4}$

\section{2. - a as the old demonstrative}

Manterola $(2006,2009)$ has a different view of the status of $-a$ - in the inessive. He has developed the hypothesis that the Basque declensional paradigm results from the cliticization or phonological reduction of the old demonstrative paradigm. The presence of the epenthetic vowel thus follows from the fact that the old locative demonstrative (nowadays the adverbial demonstrative han 'there') had an initial aspiration (still perceivable in some eastern varieties) that triggered the presence of the epenthetic vowel (the star character represents a reconstructed, non attested form):

(16) lur 'earth' + han 'there' $\rightarrow$ *lur-e-han 'in the earth' $\rightarrow$ lur-e-an

One obvious problem with this view is that the article itself does not give rise to the epenthesis, despite the fact that its older demonstrative form ha 'that' was

2. According to De Rijk (1981), the forms without a genitive that we find in modern Basque, such as lagunagan $(<$ lagun $+a+g a+n)$, should be later innovations, because they maintain the intervocalic consonant. Textual evidence suggests, to the contrary, that the genitive-less forms are actually the primitive ones, weakening De Rijk's line of reasoning (see Santazilia 2013, for a recent summary of the issues involved from a historical point of view). I have nothing to add here.

3. As noted by a reviewer, this is not a process postulated ad hoc for this affix, but a widely attested phonotactic process in Basque which affects all voiced stops (cf. Michelena 1990), and even sibilants in some dialects (cf. Hualde 1993).

4. The presence of the ergative in locative phrases would not be a peculiarity of Basque. It arises in other ergative languages, for instance in the Daghestanian language family (cf. the discussion on the local cases of Tabasaran, and the relation of the ergative case to oblique stems in Tsez, in Comrie and Polinsky 1998: 98-99), and in Hindi, where the ergative case is added to oblique case morphemes typical of locative phrases (as discussed by Mohanan 1994 and Markman 2012, among others). 
also aspirated. In other words, the evolution schematized in (17) has no place in the diachrony of Basque.

(17) lur 'earth' + ha 'that' $\rightarrow$ *lur-e-ha $\rightarrow$ lurrea

To address this asymmetry, Manterola suggests that the grammaticalization paths leading from the demonstrative to the article in Basque happened in different historical periods for the locative and the absolutive. Manterola's diachronic hypothesis for the emergence of the determiner in Basque and its relation to the special morphosyntactic properties of inessive phrases combines well with some of the observed synchronic asymmetries in the behaviour of the nominal grounds in inessive phrases. In the next section I describe those properties and propose a different way of approaching them which does not assume an underlying determiner. ${ }^{5}$

\subsection{Phenomena targeting $D$ and the inessive}

The idea that -an is something other than a sequence of a determiner plus a declension suffix faces several well known problems. All of them revolve around the fact that $-a$ - in $-a n$ is targeted by several phenomena which seem to affect determiners generally in Basque. Consider the contrast in (18a-c) (adapted from Artiagoitia 1997, 2000, 2012):

(18) a. Hiri*(-a) oso ederra da. city-D very nice is

'The city is very beautiful.'

b. Bilbo(*-a) oso ederra da. Bilbao-D very nice is 'Bilbao is very beautiful.'

c. Aitor (*-a) oso ederra da. Aitor-D very beautiful is 'Aitor is very beautiful.'

As shown in the examples, only common nouns accept the determiner, which is obligatory when a noun phrase is in argument position in Basque (18a). ${ }^{6}$ Proper nouns, whether corresponding to animate entities or locations $(18 \mathrm{~b}, \mathrm{c})$ do not take the article. Artiagoitia observes that proper nouns must take an article when they are modified:

(19) a. Aitor zahar*(-a) ongi ikusi dut.

Aitor old-D well seen AUx[1sE-3sA]

'I saw old Aitor in good shape.'

b. Bilbo berri *(-a) zoragarria da.

Bilbao new-D great-D is

'The new Bilbao is great.'

5. What I will say here does not necessarily question Manterola's larger hypothesis regarding the origin of the declensional system as a whole.

6. Except for the Souletin dialect which admits bare noun objects (see Etxeberria 2011). 
He provides an analysis à la Longobardi (1994), whereby the intervening presence of the adjective precludes the movement of the proper noun to the Spec of DP. In the absence of an overt specifier in DP, an article must lexicalize the projection. As noted by Artiagoitia, the same alternation targets the inessive suffix: more concretely its first component $-a$. The alternation is difficult to discern in the case of animate proper nouns, for the reason that the animate suffix -ga-, potentially different from the article $-a$, must surface in that case. But it is easy to identify in the case of locational proper nouns, which do not take -ga. In that case, the first element of the sequence - an disappears, as we would expect if - $a$ were the article:

(20) Bilbo-(*a)-n dago.

Bilbao-D-INESS is

'He/she/it is in Bilbao.'

If the proper noun is modified by an adjective, the article must show up again:

(21) Bilbo zaharr-e-a-n ikusi nuen.

Bilbao old-EPENTH-D-INESS see AUx[1sE-3sA]

'I saw him/her/it in old Bilbao.'

In an analysis à la Longobardi (1994), it is difficult to interpret these data as showing anything other than the first element in the sequence -an is the article. The conclusion would be supported by alternations between definite and indefinite inessive cases in those dialects which allow bare nouns with an indefinite reading. Thus, in Souletin and some Low-Navarrese varieties, one can find alternations of the following sort: ${ }^{7}$
Etxen

is
da.
b. Etxe-a-n da.
'He/she/it is home.'
house-D-INESS is
'He/she/it is in/at the house.'

With a bare noun following the inessive suffix, the meaning of the locative phrase approaches something like English (at) home. With the article, the reading is that the house is either someone else's house, or that it is viewed as a mere container. This corresponds roughly to the alternative use of (at) home versus at the house in English. To the extent that this type of alternation only arises in varieties which independently allow for bare nouns to occur in predicate and (some) argument positions, it could constitute further evidence in favour of the idea that the complex morpheme -an must be decomposed into a Determiner - $a$ and the inessive suffix $-n$. The alternation constitutes clear evidence against a monomorphemic analysis of the locative ending. But it does not, in and of itself, constitute evidence

7. To be precise (22b) is actually pronounced etxín, from etxe- $a-n$, with vowel dissimilation motivated by the underlying presence of the article, and subsequent vowel reduction. 
against De Rijk's view that the element preceding the inessive is not the article. It could well be that in (22a) the suffix - $g a$ (to be precise, its weakened version - $a$-) is not present at all. The apparent absence of the article in those cases therefore would have to be interpreted more perspicuously as the absence of the -ga suffix, which we compared to the ergative.

The data in (21) and (22) can be interpreted differently if proper nouns enter the syntax as predicates, as ordinary common nouns do. This idea has been recently defended by Matushansky (2008), on the basis of a cross-linguistic analysis of naming constructions of the type in $(23 \mathrm{a}, \mathrm{b})$ :

(23) a. The king of England was called Arthur.

b. Call me Al.

According to Matushansky, such naming verbs have the same underlying structure as verbs of nomination. Stowell (1989) argues that verbs of nomination take a small clause complement. Thus, a sentence like (24a) would have the underlying structure in (24b):

(24) a. The queen appointed her lover treasurer of the realm.

b. The queen appointed [ $\mathrm{SC}$ her lover treasurer of the realm]

Verbs of nomination in Basque, which have been claimed to possess a similar predicative structure (see Zabala 1993) also possess a bare noun in predicate position:

(25) Aitor lehendakari izendatu zuten.

Aitor president nominated AUX[PAST.3PLE-3sA]

'They nominated Aitor president.'

Proper names in naming constructions behave in an identical fashion: it is to be thought that the absence of a determiner in the proper name Bilbo in (26) follows from the same reasons that motivate the absence of an article in the predicate of nomination verbs:

(26) Herri ttipi hura Bilbo deitu zuten. village small that Bilbo called AUX[PAST.3PLE-3SA]

'They called that small city Bilbao.'

What verbs of nomination show is that proper nouns, including locational proper nouns can show up in different syntactic guises: in argument position, they will combine with a determiner, as common nouns do in Basque; in predicative contexts they will occur in their bare form. There is no particular reason why the geographical proper noun should take a determiner in the domain of adpositional phrases. In fact, there are good reasons to think that geographical 
proper nouns may involve a lighter structure in inessive phrases than they do in argument position. One reason to think so is that, at least in the context of inessive phrases, geographical proper nouns can be directly compounded with a locational noun: ${ }^{8}$

(27) a. Bilbo-ondoan bada sagardotegi eder bat. Bilbao-next-INESS AFF.is cider house great one 'Next to Bilbao there is a great cider house.'

b. Bilbo-inguruan aurkitu dute gorpua. Bilbao-surrounding-INESS found AUX[3PLE-3SA] corpse-D 'They found the corpse in the area surrounding Bilbao.'

c. Irun-parean baduzu Hondarribia. Irun-vis-à-vis-INESS AFF-AUX[2sE-3sA] Hondarribia 'In front of Irun, you have Hondarribia.'

d. Bilbo erdi-erdian dago eraikin hori.

Bilbo middle-middle-INESS is house that 'That house is at the very center of Bilbao.'

DPs are excluded from this kind of compound:

(28) a. Herri inguruan dago. village surrounding-INESS is 'It is somewhere in the surroundings of the village.'

b. *Herria inguruan dago. village-D surrounding-INESS is

Recall in this regard the Souletin facts again: if the noun etxe, like English home, denotes the space within which the speaker lives, in other words, a customary place, the determiner is not possible. If the house is employed not as a space, but as an object which can be independently compared to others, quantified and referred to, then a determiner must be added. The bare noun etxe has a behaviour that is reminiscent of the locational nouns themselves, which cannot be referential, nor can be quantified over or modified. It is the only noun that functions this way in inessive phrases in contemporary Souletin, according to Etxegorri (2013). In this regard, it is entirely parallel to the light noun home in English, as analyzed by Collins (2007). This suggests the following generalization:

(29) Place denoting bare nouns do not require - $a$ in inessive phrases.

8. A reviewer notes that even complex place names ordinarily occur without an $-a$ in Basque toponimy: Santiagomendi ( $<$ Santiago+mendi 'mountain'), Jauregizar $(<$ Jauregi 'palace' + zar 'old'), etc. 
(29) must be supplemented with (30): ${ }^{9}$

(30) Geographical bare nouns can directly denote Place

The Souletin dialect, under the description of Etxegorri (2013), provides independent evidence for the parallel behaviour of light nouns of the home type and bare geographical names. Souletin possesses two different sets of allatives (-rat and -lat) and ablatives (-rik and -tik). The distribution of those two sets of directional suffixes supports the alignment of light nouns and geographical names: -rik and -rat are used only for those two types of place denoting entitites; -tik and -lat are used for the rest (Etxegorri, 2013: 185-188).

(31) a.
Etxe-rik/rat
home-ABL/ALL
'from/to home'

(32) a. Baiuna-rik/-rat

Bayonne-from/to

'from/to Bayonne

\author{
b. etxe-tik / etxilat \\ house-ABL house-ALL \\ 'from/to a house or the house'
}

b. karrika-tik/-lat

street-from/to

'from/to a/the street'

Together, (29) and (30) suggest a different way to address the asymmetries pointed at in the beginning. The absence of $-a$ - in inessive phrases containing a proper geographical noun has nothing to do with the lack of overt determiners in the context of argument proper nouns, but with the fact that geographical locations of the rigid sort are treated as Place denoting entities, a constitutive element of locative phrases. ${ }^{10}$ In other words, the underlying structure of geographical proper nouns and light locational nouns in inessive phrases must be (33):

(33) a. [ [PP etxe-n [Place etxe]]

b. $\left[{ }_{\mathrm{PP}}\right.$ Bilbo-n [Place $\left.\left.\mathrm{Bilbo}\right]\right]$

I address the presence of $-a$ in modified geographical names in the next section.

\subsection{Non projective Axial Parts and silent Places}

An overt ground is obligatorily missing in so-called non-projective axial part constructions (a term I borrow from Fábregas 2007). Consider (34a,b):

9. The modal echoes Chomsky's observation (pointed out by a reviewer) that proper locational nouns do not necessarily denote places (Chomsky 2000: 37):

(i) London is so unhappy, ugly, and polluted that it should be destroyed and rebuilt 100 miles away.

10. See also Cattaneo (2009: 286-289) for a similar distribution of town names in Bellinzonese, a northern Italian dialect spoken in Switzerland. 
(34) a. Goian ikusi dut.

up-CM-INESS seen AUX[1sE-3sA]

'I've seen him/her/it in somewhere up.'

b. Aitor behean dago.

Aitor down-CM-INESS is

'Aitor is somewhere down.'

Goi and behe are locational nouns which denote spaces projected from the axial dimensions of an object (see section 4, for extensive discussion), but neither goian nor behean (in my dialect) can be combined with an overt ground:

(35) a.

*Mendi(aren) goian dago.

mountain-GEN up-CM-INESS is

'He/she/it is somewhere up the mountain.'

b. *Mendi(aren) behean dago.

mountain-GEN down-CM-INESS is

'He/she/it is somewhere down the mountain.'

In order for the Ground to be visible, we need to substitute goi by the relational spatial noun gain 'upperside' and behe by the allomorph pe 'downside':11

(36) a. Mendi-(aren) gainean dago.

mountain-GEN upside-CM-INESS is

'He/she/it is at the top of/over the mountain.'

b. Mendi-(aren) pean dago.

mountain-GEN downside-CM-INESS is

' $\mathrm{He} / \mathrm{she} /$ it is below the mountain/at the foot of the mountain.'

On the other hand, the terms behean and goian, even if they do not allow for an overt space denoting noun, entail reference to a location. This location (the reference object about which goi and behe predicate something) can be recovered in context:

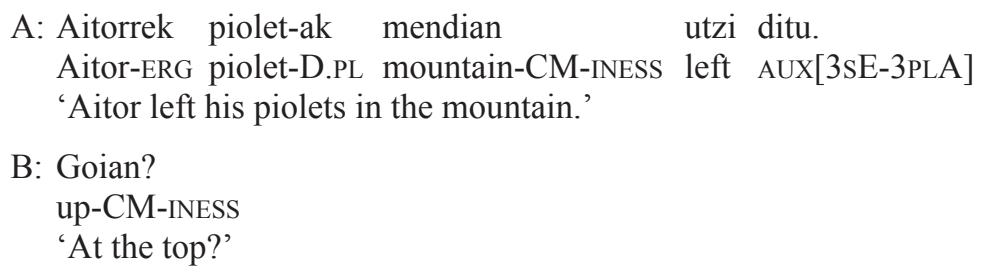

11. The distinction is clearly parallel to the one studied by Fábregas in Spanish, where one finds pairs such as delante ('lit. of-front') and alante ('lit. at-front'), both having the general meaning of 'in front of'. Delante and alante are an illustrative contrasting pair of a wider set that also includes pairs detrás/atrás 'behind', debajo/abajo 'below' and encima/arriba 'on top of'. Only the $a$-less forms are can occur with an overt ground. 
The intended meaning of B in (37) is whether Aitor left his piolets at the top of the mountain. The missing spatial ground is necessarily speaker centered, and this constitutes the basic difference with regard to relational axial parts such as gain 'upperside' or azpi 'downside'. I can say something like (38), with an anaphoric reading on kotxea 'the car' with a relational locational noun, but nothing like that can be constructed with goi or behe, which point at regions above or below the speaker, not related to the region projected from a spatial ground:

(38) a. Kotxe ederra da, baina zulo handia du azpian. car great is but hole big-D AUx[3sE-3sA] beneath-CM-INESS 'It is a great car, but it has a big hole beneath.'

b. *Kotxe ederra da, baina zulo handia du behean. car great is but hole big-D AUx[3sE-3sA] down-CM-INESS '*It's a great car but it has a big hole down.'

Behe, unlike azpi, cannot be directly related to a spatial ground. Still behe refers to a particular place, oriented in a certain way along a vertical axis whose basic frame of reference is the speaker.

When compared to geographical bare nouns or light spatial nouns, what is overtly lacking in the relevant examples is a Place component, which must nevertheless be present in the underlying syntactic representation. If we put the two types of structure side-by-side, we get the following pair of abstract representations (with silent elements in capitals):

(39) a. $\quad{ }_{\mathrm{PP}}-\mathrm{n}\left[{ }_{\mathrm{NP}}\right.$ Place $\left.]\right]$ (geographical bare nouns, light spatial nouns)

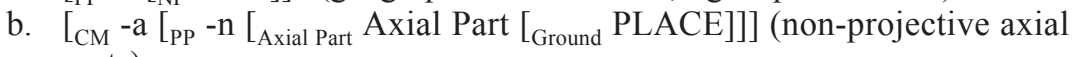
parts)

What results from a comparison between (39a) and (39b) is that the presence of the extra case-marker that we called ergative depends on the complexity of the inessive domain: the ergative arises if this domain contains more than one noun. The asymmetries between non-projective axial parts and place denoting nouns regarding the presence of the case-marker $-a$ can be formulated as follows:

(40) a. If the complement domain of the inessive adposition involves a bare Place denoting noun, the Case Marker - $a$ - is not necessary.

b. If the complement domain of the inessive adposition involves both a Place denoting and an axial part denoting noun, the Case Marker - $a$ - becomes necessary.

According to the generalization in (40), the occurrence of the ergative marker in complex geographical nouns such as (42a) can only mean that the structure involves an extra underlying noun. Since modified spatial grounds must bear genitive case in the presence of an axial part denoting nominal, as illustrated in (41), let me propose 
that in (42), the locative phrase contains a silent abstract noun denoting Place. I will remain vague for the moment as to the structure of the internal domain of the inessive head. Let us call it Ground Phrase for the time being (42b):

(41) Bilbo zaharraren ondoan

Bilbo old-D-GEN near-CM-INESS

'near old Bilbao'

(42) a. Bilbo zaharr-e-a-n

Bilbo old-EPENTH-CM-INESS

'in the old Bilbao'

b. $\left[_{\mathrm{CM}}-\mathrm{a}\left[\mathrm{PP}-\mathrm{n}\left[{ }_{\text {GroundP }}\right.\right.\right.$ Bilbo zahar ... PLACE $\left.\left.]\right]\right]$

The relative order of the elements in the adpositional phrase suggests that the overt Ground is merged to the higher CM projection. If the Souletin cases provide evidence for the final destination of the Place denoting noun, this noun must be licensed in direct construction with the inessive: ${ }^{12}$

$$
\text { [CM Bilbo zaharr-e-a [ }{ }_{\mathrm{PP}} \text { PLACE-n ...]] }
$$

In fact, the relation between the presence of more than one nominal and the occurrence of the extra case marker - $a$ - suggests a case related account of the asymmetries between (40a) and (40b). Under this view, the nominal ground is case-licensed by the ergative head, whereas the silent PLACE is licensed by the inessive adposition itself. (42b) is thus reminiscent of the structure of a transitive clause, which contains an aspectually related domain (exemplified here by the inessive postposition) and a Tense related one, defined by the presence of the ergative. It is also reminiscent of those theories of Basque ergativity which take the ergative to be a marked case, second to absolutive (see Uriagereka and San Martin 2000; Laka 2003; Rezac, Albizu and Etxepare 2013, among others).

\section{More on the syntactic status of -a-}

If the arguments in the previous section are on the right track, then the structure of Basque etxean 'in the house' is not parallel to French or Spanish á la maison, en la casa (44), modulo the head-final constraint, but corresponds rather to (44c), with the ergative marker $-a$ - selecting an inessive phrase.

12. The Souletin dialect employs -tik and -lat for modified geographical nouns, not -rik and -rat. See earlier discussion, section 2.3. 


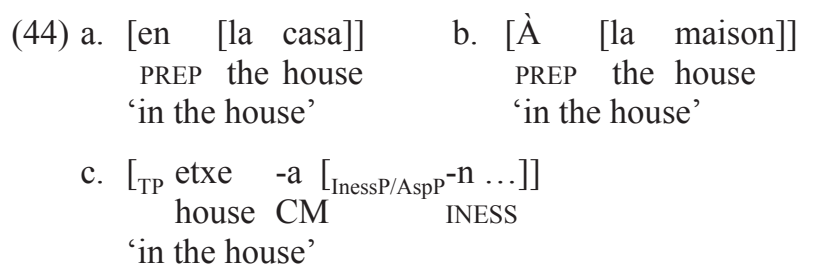

We can add at least two other arguments in support of the idea that $-a$ - is not a determiner. First, note that the purported determiner, which in Basque is often associated to familiarity and definiteness (see Etxeberria 2005) in DP arguments, is compatible with an overt indefinite article in the context of ground complements, and this with a clear indefinite interpretation:

(45) Liburua mahai bat-e-a-n dago.

book-D table one-CM-INESS is

'The book is on a/*the table.'

Sequences of indefinite and definite determiners are possible in Basque, with the meaning of 'one of the', and clear definite (and distributive) interpretation (45), none of which properties are manifest in (46):

Besides the fact that the determiner preceding the inessive presents semantic properties unlike those in ordinary nominal contexts, it also shows syntactic restrictions which are unlike those found in canonical DPs. Artiagoitia (2004) and Etxeberria (2005) have shown that the determiner $-a$ in Basque selects a number head. When the number is plural, the complex determiner head has the form $-a k$ in (47):

\section{(47) liburu-a-k \\ book-D-PL \\ 'books / the books'}

The ground complements of inessive suffixes, and of spatial suffixes in general, have the intriguing property of not accepting the plural determiner:

$$
\begin{aligned}
& \text { (48) *liburu-a-k-e-n } \\
& \text { book-D-PL-INESS } \\
& \text { 'in the books' }
\end{aligned}
$$

Number in the complement of spatial suffixes in Basque is carried by a special suffix that directly attaches to the nominal stem: 
(49) liburu-eta-n

book-PL-INESS

'in the books'

In other words, plural grounds do not admit overt determiners: the distinction between definite and indefinite plurals is realized via allomorphy: the suffix -etaencodes definiteness and plurality; the suffix - $t a$-encodes indefiniteness, and is unmarked for plurality (cf. $(50 b, c))$ :

(50) a
etxe-eta-n
house-PL-INESS
'in the houses'

b. (Hainbat) etxe-ta-n

so-many house-SUF-INESS

'in so many houses'

The asymmetry between plural and singular determiners in inessive constructions remains mysterious under the idea that the inessive postposition takes a complement headed by the determiner $-a$. The idea that $-a$ - in inessives is the article would lead us to assume sequences of definite and indefinite determiners which are otherwise unattested anywhere in Basque. ${ }^{13}$

If $-a$ - is a case-marker, akin to the ergative in the clausal domain, we must ask why it occurs in an adpositional phrase. Since Koopman's seminal paper (2000) on the Dutch adpositional system, we know that the structure of simple PPs must be extended to provide room for various functional projections. The idea behind Koopman's analysis is that in the same way that nouns and verbs project functional structure, lexical adpositions can also be shown to do so. In Den Dikken's elaboration of this idea, both Place and Path adpositions project functional structure which is akin to the one found in nominal and verbal phrases. Concretely, Den Dikken (2010: 100) proposes the following parallel functional skeleton for all lexical categories $\mathrm{N}, \mathrm{V}$ and $\mathrm{P}$ :

$$
\begin{aligned}
& \text { (51) a. } \quad\left[_{\mathrm{CP}} \mathrm{C}^{[\mathrm{FORCE}]}\left[_{\mathrm{DxP}} \mathrm{Dx} \mathrm{x}^{[\mathrm{TENSE}]}\left[_{\mathrm{AspP}} \operatorname{Asp}^{[\mathrm{EVENT}]}\left[_{\mathrm{VP}} \mathrm{V} \ldots\right]\right]\right]\right] \\
& \text { b. }\left[_{\mathrm{CP}} \mathrm{C}^{[\mathrm{DEF}]}\left[_{\mathrm{DxP}} \mathrm{Dx}{ }^{[\mathrm{PERSON}]}\left[{ }_{\mathrm{AspP}} \operatorname{Asp}^{[\mathrm{NUMBER}]}\left[_{\mathrm{NP}} \mathrm{N} \ldots\right]\right]\right]\right] \\
& \text { c. }\left[_{\mathrm{CP}} \mathrm{C}^{[\mathrm{SPACE}]}\left[_{\mathrm{DxP}} \mathrm{Dx}{ }^{[\mathrm{SPACE}]}\left[{ }_{\mathrm{AspP}} \mathrm{Asp}^{[\mathrm{SPACE}]}\left[_{\mathrm{PP}} \mathrm{P} \ldots\right]\right]\right]\right]
\end{aligned}
$$

In the adpositional field, the C-layer is involved in the extraction of adpositional heads out of the PP (Van Riemsdijk 1978), DxP is related to deixis, and the aspectual head to the bounded/unbounded status of the location or path. The deictic layer represents how the location or path is oriented vis-à-vis the speaker. Thus, locative adpositions distinguish whether the location is at the speaker's place (here)

13. We could also ask why, if - $a$ - is the ergative, it is not compatible with plural number. I will address this issue in the next section, but note that, unlike in Standard Basque, in many varieties of Basque the plural ergative and the plural absolutive are morphologically identical. This identity is based on the absolutive form (see Etxepare, in press). All those varieties keep a distinct ergative case morphology in the singular. 
or away from it (there). In Path adpositions, the head expresses whether the path is oriented towards or away from the speaker.

I will modify the Koopman/Den Dikken proposal for Basque, by contending that all three primary adpositions are in fact functional items, reminiscent of the aspectual predicates of the clausal domain. The intended rough structure for something like etxean in (1a) is the one in (52), where the primary adposition represents a functional projection of a predicate which includes a silent Place denoting entity. How this noun relates to the Ground (represented by etxe in $\mathrm{CP} / \mathrm{TP}$ ) is discussed in the next section:

(52) a. etxe-a-n 'in the house'

b. $\left[_{\mathrm{CP} / \mathrm{TP}}\right.$ etxe-a $\left[_{\mathrm{AspP}}\right.$ PLACE $\left.\left.-\mathrm{n} \ldots\right]\right]$

\section{Locational nouns in Basque}

\subsection{Extending the structure of postpositional phrases}

In addition to simple postpositions, Basque also has a rich inventory of locational nouns which allow a more flexible localisation of the figure and combine with the previous suffixes (see Euskaltzaindia 1985; De Rijk 1990, 2008; Eguzkitza 1997; Hualde 2002). An illustrative sample is provided below:

(53) a.
etxe-a-ren aurre-a-n house-D-GEN front-D-LOC 'in front of the house'
c. ohe-a-ren azpi-ra bed-D-GEN under-all '(to) under the bed'
e. errekaren inguru-a-n river-GEN space-around-D-LOC 'around the river'
b. zuhaitz-en arte-tik trees-GEN among-from 'from among the trees'
d. erreka-a-ren ondo-tik river-D-GEN next-through 'through the space next to the river'

According to De Rijk (1990), locational nouns behave as regular nouns: they require a complement with a genitive suffix, as binominal structures typically do, and bear suffixes that usually attach to nouns, such as the inessive postposition. This is illustrated in (54). Locational nouns participate in noun compounding (see De Rijk 1990 and below), and many of them have a referential use and can be followed by a determiner, as shown in (55):

(54) etxearen aurre-a-n

house-GEN front-D-INESS

'in front of the house' 
(55) a. Etxearen aurrea/aitzina konpondu beharra dago. house-GEN front fix need is 'The front/façade of the house should be fixed.'

b. Inguru hura arras hondatua zen. area that completely ruined was 'That area was completely ruined.'

c. Ondo hetan ibiltzen ginen. place that-INESS walk-HAB AUX[1PLA]

'We used to see that place quite often.'

This referential use of locational nouns however, gives rise to some subtle shifts in meaning. It is clear that aurre/aitzin 'front' identifies very different spatial entities in (56a) and (56b):

(56) a. etxearen aurre-a house-GEN front-D

'the façade/front-side of the house' b. etxearen aurre-a-n

house front-D-LOC 'in front of the house' 'in the façade/front-side of the house'

Under the «referential» use in (56a), the only interpretation of the noun aurre is 'façade' (that is, a part of the house). In (56b), its meaning is ambiguous between 'space in front of the house' (thus not a part of the house itself) 'and façade of the house'. The ambiguity disappears if we force a syntactic structure that goes beyond a bare noun. For instance, adjectival modification is only possible under the «referential» interpretation:

(57) Etxearen aurre hondatuan

house-GEN front ruined-INESS

'in the ruined façade of the house' [cf. '*in the ruined front of the house']

Adding a plural also forces a referential reading:
etxearen aurreetan
house-GEN façade-PL-INESS
b. Etxeen aurreetan
house-GEN.PL façade-PL-LOC
'in the façades of the houses'
'in the façades of the house'
[cf. '*in the fronts of the houses']

On the other hand, not all locational nouns admit a referential use. The nonreferential interpretation is the only possible one for some of those nouns. This is the case for arte 'space in between' as shown in (59): 
(59) a.

*Hango arteak meharregi ematen du.

that-GEN space in between narrow-too look-GER AUX[3sE-3sA]

'That space in between looks too narrow.'

b. Besoen artean gorde du.

arms between kept AUx[3sE-3sA]

'She kept it between her arms.'

The only possible meaning for the noun arte is that of 'space in between, projected from a ground or reference object embracing that space'. Let us call this type of interpretation a «projective interpretation». Locational nouns thus define spatial regions projected from their DP complement (Aurnague 1996). Projective interpretations are a characterizing feature of locational nouns when they are embedded in simple postpositional constructions. For Svenonius (2010), the syntactic differences between true nouns and locational nouns in their projective interpretation justifies defining the latter as a distinct functional item. Locational nouns with a projective meaning lexicalize a particular syntactic head, distinct from both the Ground (represented by the complement DP) and Place (represented by an adpositional head), that he calls Axial Part. The semantic content of the category can be described according to the following definition of axial parts by Jackendoff (1996: 14): «The axial parts of an object -its top, bottom, front, back, sides, and ends- ..., unlike standard parts such as handle or a leg, ... have no distinctive shape. Rather, they are regions of the object (or its boundary) determined by their relation to the object's axes. The up-down axis determines top and bottom, the front/back axis determines front and back, and a complex set of criteria distinguishing horizontal axes determines sides and ends.»

\subsection{Representing the axial part}

According to Svenonius (2006, 2008), Axial Parts are selected by a Place denoting adposition, the inessive suffix, and they in turn select a reference object or ground (60a,b).

(60) a. $\quad\left[\right.$ PlaceP Place $^{0}\left[_{\text {AxialP }}\right.$ AxialP $\left.\left.^{0}\left[_{\mathrm{KP}} \mathrm{K}^{0}{ }_{\text {DPground }} \cdots\right]\right]\right]$

b. $\left[_{\mathrm{PlaceP}}\right.$ in $\left[_{\mathrm{AxialP}}\right.$ front $\left[_{\mathrm{KP}}\right.$ of $\left[_{\mathrm{DP}}\right.$ the house $\left.\left.]\right]\right]$

Axial parts in Basque are bare locational nouns, with no functional structure beyond its category feature. The nominal properties of the axial part head have a reflex in Case assignment: the ground term either receives genitive case (61a) or forms a compound with the axial noun (61b):

(61) a. etxearen aurrean house-GEN front-CM-LOC 'in front of the house' b. etxe-aurrean house front-CM-LOC 'in front of the house' 
The apparent fully nominal status of Basque locational nouns could be accomodated in Svenonius cartography under the assumption that the locational noun denoting an axial part as well as its associated ground merge with the Axial Part phrase, restricting its interpretative range (Borer 2005):

(62) a. etxearen aurre-a-n

house-D-GEN front-CM-INESS

'in front of the house'

b. $\left[_{\mathrm{TP} / \mathrm{CP}}-\mathrm{a}\left[\mathrm{PP}-\mathrm{n} \ldots\left[_{\mathrm{PossP}}\right.\right.\right.$ etxearen aurre $\left.] \mathrm{Ax}^{0} \ldots\right]$

For other authors working on languages typologically closer in this regard to Basque, the relation linking the axial part denoting noun and the ground is at the bottom a predicative relation. Aboh (2010) claims, on the basis of evidence gathered from Gbe languages, that universally, the underlying structure relating grounds and locational nouns of the axial part sort is a basic predicational relation, akin to possessive constructions as analysed by Kayne (1994). Thus axial parts are the nominal complements of a silent functional head (63) encoding possession:

(63) ${ }_{\mathrm{PP}} \mathrm{P}\left[{ }_{\mathrm{IP}}\right.$ Reference object I $\mathrm{I}^{0}$ Locational Noun]]

The apparent compounds constructed on locational nouns, such as (64), seem to be at odds with the predicative relation proposed by Aboh:
(64) a. ur-azpian
water-beneath-CM-INESS
'beneath the water'
b. etxe-inguruan house-area-CM-INESS 'around the house'

There is no simple way to derive a compound from a basic structure like (63), at least under the traditional notion of compound as a means to produce new lexical roots. But some of the locational nouns involved in apparent cases of compounding require semantic arguments which would seem to go beyond a bare nominal category. Take for instance arte 'between':

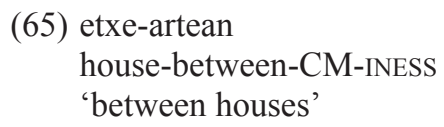

(65) etxe-artean

house-between-CM-INESS

'between houses'

As the English translation shows, the denotation of the argument of the locational noun in this case must be something close to a plural. Although arte 'between' is lexically designed to select plural denotations, other locational nouns which are not necessarily so designed also present ambiguities in this regard. Take for instance (66): 
(66) Context: Jon was working in his private library when a sudden earthquake caused all the books to fall on him. Someone comes to help him, and tells the situation as follows:

Gizarajoa liburu-pean itota aurkitu genuen.

poor-D book-under flooded found AUX[1PLE-3SA]

'We found the poor guy flooded under books.'

In (66) the salient meaning (in fact the only felicitous one) is one in which the poor guy is beneath a big quantity of books. But we could force a singular reading by changing the context. Imagine that Jon is a collector of books, and that he particularly likes big books of the sort used for group singing in monastic communities. He has one of those just above him in his library. An earthquake erupts, and the book falls on him. It's an enormous book, which covers half of his body when wide open. Under this context we could use the same sentence, and the meaning would be that Jon happens to be beneath an enormous book. What this seems to show is that the denotation of the spatial ground in the apparent compound cases embraces both singular and plural readings. This is reminiscent of the notion of classifier phrase in Borer's system (2005). Classifiers, represented by the so-called plural suffix $-s$ in English, project the denotation of a bare noun into a set of possible atoms and sums of atoms. The classifier portions out the denotation of the bare noun so that it can be available for quantification. Etxeberria and Etxepare (2012) have argued extensively in favour of such a layer of structure in the context of some of the Basque existential quantifiers. I will just assume that the underlying structure of the spatial ground in the relevant cases involves a minimal syntactic structure composed by a bare noun and a classifier in Borer's sense. In other words, what (64)-(65) show is that what we have identified as a compound, potentially involving a $\mathrm{N}+\mathrm{N}$ root, is actually a syntactic object involving some minimal functional structure for at least one of the two nominals. This minimal functional structure is headed by a classifier:

(67) $\left[_{\text {ClassP }} \mathrm{CL}[\right.$ Ground $\left.\mathrm{N}]\right]$

If (67) is an available option (perhaps the only one) for the ground, we must ask what type of syntactic relation can be such as to allow combining (67) with a bare nominal like the locational noun. A straightforward possibility is Aboh's predicative structure:

$$
\left[_{\text {IP }}\left[{ }_{\text {NumP }} \mathrm{CL}^{0}\left[_{\text {Ground }} \mathrm{N}\right]\right] \mathrm{I}^{0}[\mathrm{~N}]\right]
$$

\subsection{Frames of reference and syntactic structure}

Further evidence in favour of a basic predication relation between the spatial ground and the axial part in the context of apparent compounds can be gathered from the kind of perspectival asymmetry that Rooryck and Vanden Wyngaerd (2007) have studied in the domain of locative phrases. Rooryck and Vander Wyngaerd note, 
following Cantrall (1974) that the relation between the axial part denoting noun and the spatial ground can be interpreted in terms of two different frames of reference, that they call «object-centered frame» and «observer-centered frame». This difference is particularly prominent when the spatial ground is animate, and can be alternatively conveyed by either a pronominal or an anaphor. Consider in this regard the following contrast (Rooryck and Vanden Wyngaerd 2007: 35):

(69) a. They placed their guns, as they looked at it, in front of themselves/*them.

b. They placed their guns, as I looked at it, in front of *themselves/them.

If the perspective is that of the subject, they observe, only the anaphor is possible. If the perspective is that of the speaker, only the pronoun is. An interpretive effect also related to the alternation between pronominals and anaphors concerns the locative configuration combining the axial part and the ground (Rooryck and Vanden Wyngaerd 2007: 36):

(70) a. Mary kept her childhood dolls close to her (=proximity/vicinity).

b. Mary kept the childhood dolls close to herself (=against her body).

The difference between the use of a pronoun or an anaphor correlates with a difference in the nature of the location of the dolls with respect to Mary. In Rooryck and Vanden Wyngaerd's terms, «the use of the pronoun allows for a relatively abstract location of the dolls: the dolls could be at her home, for example, even if Mary might be out of the house at the moment (70a) is uttered». In contrast, «the use of the anaphor forces a very concrete locative interpretation, where the dolls are in contact with Mary's body». For the authors, the two differences in meaning arising from the use of anaphors versus pronouns are related. They follow from the kind of abstract agreement relation which is available in the anaphor case to the spatial ground and the axial part noun. For Rooryck and Vanden Wyngaerd, anaphors, unlike pronouns, include an axial part, represented by the morpheme self. The object-centered relation arises as the result of an Agree relation between an object with axial features and the Axial Part features embedded in the adpositional phrase. Rooryck and Vanden Wyngaerd resume their proposal in the following two hypotheses (2007: 41):

(71) a. The object centered interpretation is the result of an Agree relation internal to the PP between an Axial Part and axial features of its complement DP

b. The observer-centered interpretation is a result of a binding relationship between Axial Part and something external to the PP, the Speaker.

If we come back to the examples in $(70 \mathrm{a}, \mathrm{b})$, their structural differences can be represented as follows: 
(72) a. Object centered interpretation

They placed their guns, as they looked at it, ...

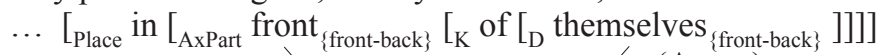

(Agree)

b. Speaker/observer centered interpretation

They placed their guns, as I looked at it, ...

$\ldots$ [Place in $\left[{ }_{\text {AxPart }}\right.$ front $_{\{\text {Speaker }\}}\left[_{K}\right.$ of $\left[{ }_{D}\right.$ them $\left.\left.\left.]\right]\right]\right]$

In (72a) the Axial Part front agrees with the axial dimensions provided by the complex anaphor himself. This forces an object-centered perspective. In (72b) the simplex pronoun him, lacking axial dimensions, blocks the Agree relation with the Axial Part front (Rooryck and Vanden Wyngaerd 2007: 49). As a result, the Axial Part will be bound by some element in the deictic field of the utterance, typically the Speaker. The variation in the interpretation of location with anaphors and pronouns would also capitalize on the same syntactic differences: the existence of an Agree relation between the Axial Part and the axial features provided by self in the anaphoric spatial ground force a strictly locative interpretation: the dolls in (72b) must be in contact with Mary's body. In contrast, the pronoun lacks Axial Parts and therefore spatial dimensions. The non-agreeing Axial Part is bound externally by the Speaker, and the interpretation is one that evaluates closeness from the point of view of the speaker. This interpretation allows for a non-strictly locative meaning and a subjective notion of closeness.

Although Basque does not present the same alternation between anaphors and pronouns in the context of locative phrases, the syntactic status of the Ground has an effect in the available locative readings. Take for instance the following contrast:

(73) a. Helikoptero bat zebilen untziaren gainean.

helicopter one worked ship-GEN top-CM-INESS

'A helicopter was operating above the ship.'

b. Helikoptero bat zebilen untzi-gainean.

helicopter one worked ship-top-CM-INESS

'A helicopter was operating on the surface of the ship.'

With a genitive marked ground, the sentence can be interpreted as meaning that a helicopter was operating above the ship, to an undetermined height. Without a genitive ground, the meaning of the locative phrase seems to convey that the helicopter is operating on the surface of the ship. This interpretation requires a contact situation between the ship and the helicopter, something strange from the point of view of our world knowledge. Take also the following: 
(74) a. Zakurrak lore-artean egiten du lo ... dog-ERG flower-among-CM-INESS do-GER AUX sleep ... \#harentzat prestatu genuen kaxota batean. him-for prepared AUX house one-CM-INESS 'The dog sleeps among the flowers in a house we prepared for him.'

b. Zakurrak loreen artean egiten du lo $\quad \ldots$ dog-ERG flower-PL.GEN between-CM-INESS do-GER AUX sleep ... harentzat prestatu genuen kaxota batean. him-for prepared AUX[1PLE-3SA] house one-CM-INESS 'The dog sleeps between the flowers in a house we prepared for him.'

Whereas in the bare predicational structure in (74a), the dog sleeps literally among the flowers, in contact with them (hence the oddness of the continuation), in (74b), with a genitive ground, the interpretation allows a reading in which the dog is not in contact with the flowers, but in some space bounded or surrounded by them. Again, the bare predicative construction, unlike the genitive one, entails contact between the axial part and the ground.

Following Rooryck and Vanden Wyngaerd, I take the meaning difference to be related to a different underlying syntax: whereas it is conceivable that a noun phrase enters an agreement relation in the context of a predicative structure, it is not conceivable that genitive arguments do. Unlike NPs, genitive phrases do not participate in agreement in Basque.

Let me propose that the predicative relation between the ground and the axial part in Basque is realized along the lines of Aboh's proposal:

$$
\left[_{\text {IP }}\left[{ }_{\text {NumP }} \mathrm{CL}^{0}\left[_{\text {Ground }} \mathrm{N}\right]\right] \mathrm{I}^{0}[\mathrm{~N}]\right]
$$

If the Ground is definite, then it must be case-licensed by the genitive: ${ }^{14}$

(76) $\left[_{\mathrm{KP}}\left[\left[_{\text {Ground }} \mathrm{DP}\right]-\mathrm{K}_{\mathrm{Gen}}\right] \mathrm{I}^{0}[\mathrm{~N}]\right]$

Genitives do not license agreement in Basque, and therefore they do not give rise to contact readings in an obligatory fashion.

\subsection{Binding versus Agree, and the complement of I}

(75) raises a question regarding the non-projective axial parts that we studied in section 2.4. Those axial parts present the following properties: (i) they are necessarily interpreted from the point of view of the speaker; (ii) they do not license an overt ground, in any of the conceivable forms (77a,b); (iii) they nevertheless entail the presence of a place denoting entity, which we took to be represented by a silent Place, as in (78):

14. Artiagoitia (2012) argues convincingly that genitive case is checked in a functional projection external to the basic predicative layer. I will leave aside this issue, as it is not of immediate relevance. 
(77) a. (*mendiaren) goian mountain-GEN up-CM-INESS 'on top (of the mountain)' b. (*mendi)-goian mountain-up-CM-INESS 'on top of the mountain'

(78) $\left[_{\mathrm{CM}}-\mathrm{a}\left[\mathrm{PP}-\mathrm{n}\left[{ }_{\text {Ground }}\right.\right.\right.$...Axial Part PLACE $\left.\left.]\right]\right]$ (non-projective axial parts)

It is not clear how (78) fits in the predicative structure established in (75) and (76). To start with, (78) lacks a spatial ground, one of the component entities in the predication relation. One possibility is that in non-projective cases this apparently absent ground is realized by silent pro, as suggested by Fábregas (2007) in the context of Spanish non-projective axial parts:

(79) a. goian

up-CM-INESS

'At the top'

b. $\left[_{\mathrm{TP} / \mathrm{CP}}-\mathrm{a}\left[\mathrm{PP}-\mathrm{n}\left[{ }_{\mathrm{IP}}\right.\right.\right.$ pro $\mathrm{I}^{0}$ [goi]]]

The structure in (79b) has several problematic aspects, though. One is why pro must remain silent in those cases. It is interesting to compare (79) with $(80 \mathrm{a}, \mathrm{b})$, which involve a relational locational noun. In the latter, the ground may be optionally silent, but it is recoverable in a way which suggests the underlying presence of a pronominal anaphor (80b):

(80) a. etxearen aurrean

house-GEN front-CM-INESS

'in front of the house'

b. Etxe ederra da, eta aurrean lorategi bikaina dago. house great is and front-CM-INESS garden extraordinary is 'It is a great house, and there is an extraordinary garden in front (of it).'

Relational locational nouns provide a good basis for the claim that an underlying pro exists, but non-relational ones do not. Non-relational locational nouns say something about the location of a space which does not depend on a conventional ground. In other words, the basic stuff underlying locational nouns in inessive constructions seems to involve three things, not two: an abstract Place denoting noun, a locational noun, and a spatial Ground in the case of relational locational nouns. This extra spatial argument must be related at some point or other by predication to the locational noun, which on the other hand, does not obligatorily require it. Let me start by the non-projective cases, which must relate an axial part denoting locational noun and a Place denoting entity. Let me call this structure a small clause:

[Small Clause PLACE Axial Part] 
That the Axial Part functions as a predicate in these cases is evidenced by the fact that it admits reduplication (an observation due to Aurnague 1996), a property which nouns only acquire in predicative position:
a. Mikel ume-umea da oraindik.
Mikel child-child-D is still
b. Behe-behean
dago.
'Mikel is still very childish.'
down-down-CM-INESS is
'It is at a very low place.'

The spatial ground, which is not present at this level, must be added by means of further functional structure. Let me suggest that this further functional structure is the possessive Infl proposed by Aboh for the locative phrases in Gbe:

$$
\text { [PossP } \text { Ground Poss }\left[\text { Small Clause }_{\text {PLACE Axial Part }]}\right.
$$

The Axial Part incorporates into the inflectional head, and enters in an agreement relation with the specifier of the higher projection:

$$
\text { [PossP Ground Poss }+ \text { Axial Part [Small Clause PLACE Axial Part] }
$$

The structure in (84) yields some interesting consequences regarding the perspectival issues discussed in the preceding section. (84), as it stands, is what Chomsky (1986) called a Complete Functional Complex, that is a fully fledged binding domain, with an overt subject occupying the Spec of IP. Binding relations therefore, are bound to happen inside the IP, not outside. (81) on the other hand, lacks a formal subject. It is in this context that the Place component is necessarily interpreted as bound by a higher Speaker index. Capitalizing on the parallel we have established between clauses and adpositional phrases, this indexical element will be inserted in C, just above the TP hosting the ergative case (see Baker 2008, for a similar proposal in the context of indexical shift phenomena):

$$
\left[{ }_{\mathrm{CP}} \text { Speaker }_{\mathrm{i}} \mathrm{C}\left[_{\mathrm{TP}}-\mathrm{a}\left[{ }_{\mathrm{AspP}}-\mathrm{n}\left[\mathrm{sC}_{\mathrm{SC}} \text { PLACE }_{\mathrm{i}} \text { Axial Part }\right]\right]\right]\right.
$$

(84) is also the structure underlying the Souletin light noun etxe 'home'. Etxen in Souletin can only make reference to the speaker's own house:

(86) $\left[\right.$ Speaker $_{\mathrm{i}} \mathrm{C}\left[\mathrm{AspP}_{\mathrm{A}}\right.$ etxe $_{\mathrm{i}}-\mathrm{n}\left[_{\text {Place }}\right.$ etxe $\left.\left.\left._{\mathrm{i}}\right]\right]\right]$

\subsection{Referential and projective locational nouns}

We have mentioned at the beginning of section 4 , that locational nouns may have a projective or a referential interpretation. This ambiguity is repeated here:

(87) etxearen aurre-a-n

house-GEN front-CM-INESS

'in front of the house' / 'in the façade of the house' 
The second interpretation, expressing a part-whole reading, is associated to the possibility of number, adjectival modification and independent reference, as evidenced by the following cases:

(88) a. etxearen aurre hondatu-eta-n

house-GEN front run-down-D.PL-INESS

'in the run-down façades of the house'

b. etxearen aurre horretan

house-GEN front that-INESS

'in that façade of the house'

Whatever allows this reading, must be happening in the domain of the inessive, as the relevant syntactic features are pied-piped to the edge of the adposition. One possibility is that the inflectional head heading the possessive phrase can optionally select for number features and determiner like projections, such as the demonstrative. In this case, there will not be an abstract PLACE noun, but the axial part aurre, «nominalized» to denote part of an object, constitutes the predicate:

[PossP Ground $\operatorname{Poss}^{0}\left[\right.$ DemonsP $^{0} \mathrm{D}_{\mathrm{NumP}} \mathrm{Num}^{0}\left[_{\mathrm{N}}\right.$ aurre $\left.\left.]\right]\right]$

In this case, the predicate raises to Number, instead of incorporating to the possessor head.

Given the asymmetric nature of predication, whereby predicates are typically lower in the referential scale than subjects, we expect that bare nominal grounds of the sort we have seen in object centered locative structures will not be available here. This prediction is borne out:

(90) a. etxe-*(aren) aurre horretan

house-GEN façade that-CM-INESS

'in that façade of the house'

b. Etxe-*(aren) aurre hondatuan

house-GEN front run-down-CM-INESS

'in the run down façade of the house'

\section{Inessives and elision}

One intriguing property of singular inessive phrases is that (at least for a subset of Basque speakers) they do not license partial nominal ellipsis in relative clauses. Consider in this regard (91): 
(91) Bera bizi zen lekuan argia zuten, he/she-ABS live Aux[PASt.3sA] place-D-INESS light Aux[PASt.3PLE-3SA] ??baina gu bizi ginen-Ø-e-an ez. but we-ABS live AUX[PAST.1PLA]-D-INESS not 'In the place where he/she lived they had light, but in the one we lived, we didn't.'

The noun leku 'place' corresponding to the relativized noun in the antecedent clause can not be elided in the second one. This fact is surprising when we see that nominal ellipsis is possible under an ordinary determiner in relativization:

(92) Bera

bizi zen

leku-a ederra zen, baina gu bizi he/she-ABS live AUX[PAST.3sA] place-D nice was but we-ABS live ginen(-a/hura) ez. AUX[PAST.1PLA]-D/DEM not

'The place she/he used to live was nice, but the/that one we lived in was not.'

The effect is stronger when the elision doesn't follow from structural identity with an antecedent. In this case, only an independent temporal reading is available:

(93) Hura aspaldiko hilobiz betea zegoen, eta hezurrik aurkitzen zutenean that long-ago tombs full was and bones find-HAB AUX-REL-LOC marka bat jartzen zuten. sign one put AUX[PAST.3PLE-3sA]

'That area was full of ancient graves, and when/*where they found bones, they put a sign on them'

If the sequence Noun-D-iness corresponds to a syntactic structure that includes the one corresponding to the partial sequence $N-D$, it is not clear why the former does not license nominal ellipsis. In both cases, a noun meaning Place would be elided. The two structures are represented in $(94 a, b)$. The silent noun, possible in (a) but not in (b) is in boldface:

(94) a. $\left[_{\mathrm{DP}}\left[\mathrm{NP}\left[\mathrm{RelP}\left[\mathrm{IP} \_\right]\right.\right.\right.$-en $\left.] \boldsymbol{\emptyset}_{\text {Place }}-\right]$-a $]$

b. $*\left[_{\text {PostP }}\left[\left[_{D P}\left[{ }_{N P}[\right.\right.\right.\right.$ RelP $[$ IP _ $]$-en $\left.\left.\left.] \emptyset_{\text {Place }}-\right]-\mathrm{a}\right]-\mathrm{n}\right]$

Partial ellipsis of Place is possible if the ground term is itself plural, or if a demonstrative is added (95). Syncretic locative cases of the -eta sort do license partial nominal ellipsis: 
(95)

a. $\mathrm{Zu}$ ibiltzen zinen parajeetan pizti asko you-ABS frequent-HAB AUX[PAST.2SA]-REL area-INESS-PL animal many aurkitzen ziren, find-HAB AUX[PAST. 3PLA]

baina ni ibiltzen nintzen-Ø-e-tan ez.

but I-ABS frequent-HAB AUX[PAST.1SA]-REL- INESS-PL not

'In the areas you used to go to, there were many animals, but in the ones I used to go, there weren't.'

b. Hura aspaldiko hilobiz betea zegoen, eta hezurrik aurkitzen that long-ago tombs full was and bones find-HАB zuten-Ø-etan marka bat jartzen zuten AUX[PAST.3PLE-3sA]-REL-PL-LOC sign one put-HAB AUX[PAST.3plE-3sA] 'That area was full of ancient graves, and when/where they found bones, they used to put a sign on them.'

I would like to relate the ungrammaticality of those cases to the impossible (96):
*Ondoan
bizi da, baina bizi d-en ondoan
ez nuke nik

next-D-INESS live is but live is-REL next-D-INESS not I-would I-ERG

bizi nahi.

live want

'He lives nearby, but at the nearby place he lives in, I would not like to live.'

Relativization of locational nouns is impossible. This is predictable if the object of relativization cannot directly be an axial part, but a place denoting noun. The silent Place in the inessive phrase under the structure we assigned to inessive phrases, is arguably trapped inside a clause-like constituent, closed off by the axial part in Spec of TP/CP: ${ }^{15}$

$$
*{ }^{[\mathrm{TP} / \mathrm{CP}} \text { ondo }-a\left[\left[_{\mathrm{AspP}} \text { PLACE }-n[\text { GroundP } \cdots]\right]\right]
$$

Relativization is possible with plural locations (cf. 95). For the plural cases, I will contend that they do not have an abstract PLACE denoting noun, but that the same function is performed by the locative suffix -ta-, a functional counterpart of the abstract noun. - $T a$ - is an inner functional head with a function akin to that of the abstract noun, which I will tentatively define as projecting an object into the region it occupies:

15. Alternatively, Place denoting abstract nouns, having no phi-features, cannot relate to the structure projected by the relative clause in any grammatically meaningful way. That the relative phrase projects independent functional structure is shown by contrasts such as (i) (Kayne 1994):

(i) a. *the Paris

b. the Paris I know 
(98) a. Parajeetan 'in the spots'

b. $\left[_{\text {InessivP }}-\mathrm{n}\left[\right.\right.$ DP/NumbP $-\mathrm{e}-\left[_{\text {LocP }}-\right.$ ta $[$ paraje $\left.\left.\left.]\right]\right]\right]$

The derivation involves movement of paraje to the Locative Phrase headed by -ta-, and subsequent movement of the same noun through Number and D (99a). The definitive word order is achieved by rolling up movement of the DP into the inessive phrase (99b):
a. $\left[_{\text {InessivP }}-n\left[_{\mathrm{DP} / \mathrm{NumbP}}\right.\right.$ paraje $-e-\left[_{\text {LocP }}\right.$ paraje $-t a[$ paraje $\left.\left.\left.]\right]\right]\right] \rightarrow$
b. $\left[_{\text {InessivP }}\left[\mathrm{DP} / \mathrm{NumbP}\right.\right.$ paraje $-e-\left[_{\text {LocP }}\right.$ paraje $-t a[$ SC paraje $\left.\left.]\right]-n \ldots\right]$

\section{Adding Path}

One obvious question that arises under this analysis is why the extra case-marker in inessive phrases is absent in the presence of Path denoting adpositions (100). Why should the presence of a Path feature prevent the emergence of the extra case-marker?
(100) a. Etxe-ra
house-ALL
b. $\operatorname{Etxe}(* a)-r a$
'to the house' house-CM-ALL
'to the house'

If we avail ourselves from the complex structure that cartographic approaches attribute to Path denoting adpositions (see (3)), there is a straightforward reason why allative adpositional phrases should be simpler than inessive ones. Allative adpositional phrases lack an extra-case assigner (the one we called ergative) because, as complex adpositions, they already possess the functional structure necessary to case-license two nouns. The Path head case-licenses the overt noun, and the locative head licenses the silent noun:

(101) $\left[_{\text {PathP }}\right.$ etxe P $\left[_{\text {PlaceP }}\right.$ PLACE P $\left.\left.\left[{ }_{\text {AxP }} \cdots\right]\right]\right]$

If the Path licenses the case of the overt noun, no other case assigner is required, and therefore it is not projected (see the notion of economy of projection in Boskovic 1995):

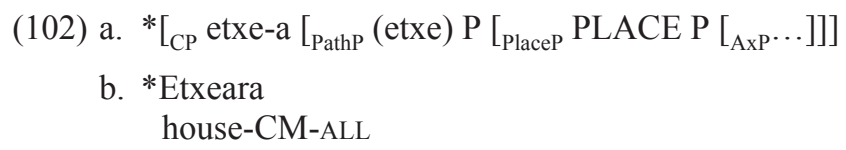

One of the consequences of this analysis is that the lexicalization of spatial features can operate on syntactic phrases and does not necessarily target heads. This is in accord with the nano-syntax project (as spelled out in Starke 2009; see Caha 2009, for the concrete domain of adpositions and cases). Under the approach 
defended in this paper, lexicalization of spatial adpositions proceeds from less to more inclusive feature sets: the inessive lexicalizes Place, the allative lexicalizes Path and Place, and the ablative lexicalizes either Path and Place, with Path now restricted to spatial sources (see Pantcheva 2011 on «source as a reversed Path»), or Source, Path and Place:

(103) a. Inessive \{Place\}

b. Allative \{Path, Place\}

c. Ablative \{Source, Path, Place\}

In the syntactic computation, Path adpositions correspond to complex sequences of features, whose underlying presence is indirectly visible through case licensing.

\section{A tentative extension of the analysis: Persons and things}

An obvious problem for the analysis above is raised by person locatives and directionals:

$$
\begin{aligned}
& \text { (104) a. } \text { zu-ga-n } \\
& \text { you-ERG-LOC } \\
& \text { 'in you' }
\end{aligned}
$$
b. zu-ga-n-a
you-ERG-LOC-ALL
'to you'

There are several properties of person locatives and directionals that set them apart from non-personal ones. First, in person directionals we see affix stacking: the allative and the inessive are both overtly realized. Then, the order of the affixes is a puzzling one, assuming the order of - $g a$ - (ergative), allative and inessive as Tense and Aspect related categories: we would have expected (105), rather than (104b):

(105) a. *zu(re)-ga-a-n

b. $\left[_{\mathrm{TP}}\right.$ Ground DP-ERG T [ Path [ Location ... ]]]

Both properties are unexpected under the analysis we were forced to accept on the basis of the featural hierarchy in (3).

\subsection{Persons}

A relatively straightforward analysis of the order of the affixes would have the whole structure embedding the pronoun and the inessive suffix raise to the Spec of the Path phrase headed by the allative:

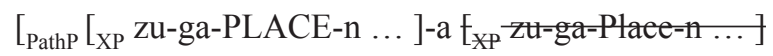

This goes against some of the technical choices we made in the analysis of the previous cases. Remember that the allative was taken to lexicalize not just Path, 
but Path and Place. This is not an insurmountable problem once we realize that in cases like (104a,b) we have a different allomorph of the allative, one which is not conditioned by the phonological context, and thus must be coded as such in the lexicon:

(107) a. -ra (Path and Place) b. - $a$ (only Path)

What is XP in (106) and why did it get there? The XP in (106) crucially involves Person. Several authors (see san Martin 2002; San Martin and Uriagereka 2001) have argued that in Basque the licensing of personal subjects requires the presence of $C$. The licensing of personal arguments ( $\left(1^{\text {st }}\right.$ and $\left.2^{\text {nd }}\right)$ is known to require wide clausal domains, unlike the licensing of third person arguments in Basque. Thus, personal pronouns cannot stay in tenseless non-finite contexts, and must raise to a the matrix finite $\mathrm{T}$. Consider in this regard the following paradigm, from Etxepare and Uribe-Etxebarria (2013):

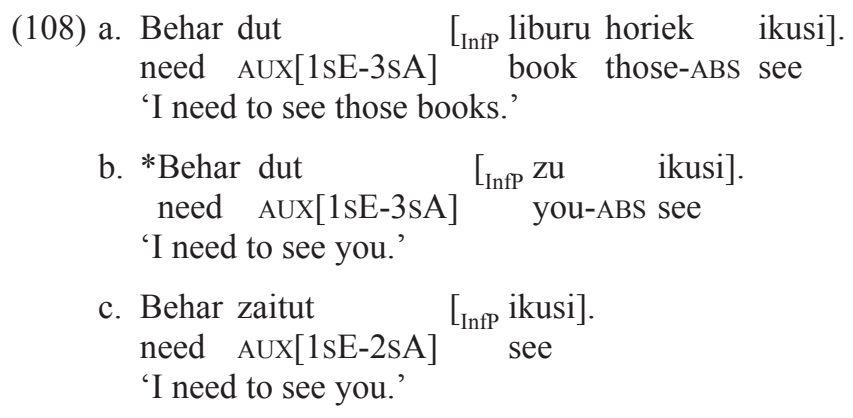

In (108), the matrix auxiliary shows singular default agreement with the nonfinite structure in its complement. It does not agree with the object of the embedded non-finite complement, which has a plural number feature. With a second person pronominal in the same position, default agreement in the auxiliary is not possible (108b) and personal agreement must obligatorily show up in the matrix auxiliary.

Ergative Case has the following particular property in Basque: it can only be licensed in the Spec of T (by Move), unlike ergative agreement, that can be licensed in-situ by Agree. Rezac, Albizu and Etxepare (in press) show several cases where the presence of an ergative suffix in contexts of raising induces scope ambiguities with regard to other operators of the clause. Purely existential arguments in the scope of intensional verbs (need/must, see below) cannot take the ergative, as in (109), with the auxiliary a transitive one, involving two sets of agreeing slots, but no ergative marking on the subject:

(109) Udaran usain txarra $\left({ }^{*} \mathrm{k}\right)$ egon behar du hor. summer-INESS smell bad-ERG be must AUX[3sE-3sA] there 'In summer there must be a bad smell there.' 
The structure reminds there-constructions in English, and suggest an analysis whereby the existentially interpreted argument has not raised to the matrix T, therefore being unable to flag an ergative.

If the ergative in (106) requires a T-C complex, then the raising of the whole clause is just $\mathrm{CP}$ movement to a Case position. This Case position is the one corresponding to the allative. Thus, the inessive takes care of the abstract noun, the ergative suffix takes care of the overt pronoun, and the allative licenses the clausal argument (see Albizu 2001 for arguments that CPs in Basque require case-licensing). Let me thus accordingly change (106) into (110):

(110) a. zu-ga-n-a

you-ERG-INESS-ALL

'to you'

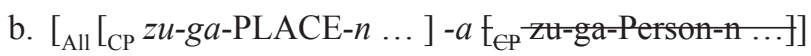

\subsection{Person and Genitive}

Consider the following asymmetry:

(111) a. ni

' $\mathrm{l}$ '

b. $\mathbf{z u}$

'you (sing.)'

c. gu

'we'

(112) a. zu-ek

you-PL

'you (pl)'

c. zu-e-n-ga-n

you-PL-GEN-ERG-INESS

'in you (pl.)' a'. ni-ga-n

I-ERG-INESS

'in me'

b'. zu-ga-n

You-ERG-INESS

'in you (sing.)'

c'. gu-ga-n

we-ERG-INESS

'in us'

a'. *zue-ga-n

you-ERG-INESS

'in you (pl.)'

Historically, the second person plural was formed by adding a plural ending to the formal singular second person $z u$ 'you' ${ }^{16}{ }^{1}$ Second person plural is the only pro-

16. Originally, $z u$ was a plural (opposed to $h i$, the singular second person, nowadays the familiar or comradeship second person), and it shows plural agreement with the auxiliary. There seems to have occurred a process similar to that of several European languages (including the languages in contact with Basque) whereby a $2^{\text {nd }}$ person singular form of respect has been created from the $2^{\text {nd }}$ person plural. Consequently, the language has developed another $2^{\text {nd }}$ person plural out of the formal one, by attaching the pluralizer -ek for both absolutive and ergative (see Martinez Areta 2013: 302). 
nominal form that has grammatically overt number. The formation of locatives out of $1^{\text {st }}$ and $2^{\text {nd }}$ person pronouns is a regular process for the grammatically singular pronouns. The grammatically plural one (zuek 'you (pl)' requires however a further case marker Genitive (-en-). This brings to mind the number restriction we found in the case of the abstract locational noun PLACE. This restriction can be accounted for under the idea that an abstract PERSON exists side-by-side to PLACE, that does not license number either. If this is the case, the PERSON abstract noun must be sheltered from number by a genitive specifier:
a. zu-e-n PERSON-ga ... yOu-PL-GEN PERSON-CM
b. you $_{\text {PLURAL }}$-r PERSON

With the whole structure as in (114):
(114) $\left[_{C P}[\right.$ zu-e-n PERSON]-ga you-PL-GEN PERSON-CM 'in you (pl)'
$[$ AspP PLACE-n...]]
PLACE-INESS

The structure in (114) is independently available to the rest of the personal pronouns, which freely alternate between the absolutive and the genitive forms:
(115) a. ni-ga-n
I-CM-INESS
'in me'
b. ni-re-ga-n
I-GEN-CM-INESS
'in me'

The possibility of having bare personal pronouns must follow from the same kind of parallelism that associates overt locational nouns to abstract PLACES: the abstract PERSON feature can be alternatively realized by the personal pronouns, when they don't possess grammatical number. This possibility is excluded for second person plural pronouns:

(116) a. $\left[{ }_{\mathrm{CP}}\left[\right.\right.$ PossP $_{\text {Pire PERSON]-ga }}$ AspP PLACE-n... ]]]

b. [CP ni-ga $\left[{ }_{\text {AspP }}\right.$ PLACE-n...]]

\subsection{Reciprocal anaphors}

Basque only has a simple anaphor: the reciprocal elkar 'each other'. This anaphor presents the following two intriguing properties: first, it requires the CM -ga-, despite the fact that the referential anchor of the anaphor (from which the anaphor inherits its referential properties) may not be animate, as in (117) (IbarretxeAntuñano 2004: 272): 
(117) Etxe hauek elkarrengandik hurbilegi daude. house these REC-GEN-CM-INESS-from close-excessive are 'These houses are too close to each other.'

Then, it must take the genitive, unlike most of the personal pronouns:

(118) a
elkarr-en-ga-n-a
REC-GEN-ERG-INESS-ALL
'to each other'

b. elkarr-en-ga-n
REC-GEN-ERG-INESS
'in each other'

In other words, something like (119) is impossible:

(119) *elkar-ga-n

rec-CM-iness

The impossibility of (119) strongly recalls the impossibility of reciprocals in subject position (Salaburu 1986, for Basque; see Rizzi 1990 and Woolford 1999, for an explanation of this type of restriction in terms of the Anaphor Agreement Effect):

(120) *Elkarr-e-k

REC-PL-ERG

The reciprocal can be embedded in subject position if it combines with another nominal:

(121) Jon eta Miren elkarren lagunek bakarrik ezagutzen dituzte. Jon and Miren-ABS REC-GEN friends-ERG only know-GER AUX[3PLE-3PLA] 'Jon and Mary are only known by each other's friends.'

The obligatory presence of the genitive in locatives with a reciprocal ground seems therefore to be related to the limited distribution of reciprocals in the context of ergative DPs. The problem with $(118 \mathrm{a}, \mathrm{b})$ is that we do not know what the nominal argument is that licenses the presence of a genitive in those cases. Capitalizing on the existence of an abstract PERSON noun, as in (116a), I suggest that the genitive depends on the presence of an abstract PERSON nominal in reciprocal locatives. The whole possessive phrase is then licensed by the ergative suffix:

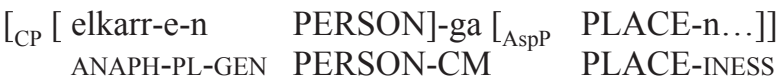

$$
\begin{aligned}
& \text { 'in each other (pl)' }
\end{aligned}
$$

This takes out much of the mistery concerning the relation between animacy and -ga-: the suffix is there to case-license nominal arguments. Its relation to animacy is derivative at best. 


\subsection{Abstract things}

Some Basque varieties located in Gipuzkoa expand the partitive determiner (see Ortiz de Urbina 1989; Etxepare 2003; Etxeberria 2010) with an unexpected inessive:
(123) a.
Ez dut lagun-ik. standard not AUX[1sE-3sA] friend-PART 'I don't have any friend.' not AUX[1SE-3sA] friend-PART-INESS 'I don't have any friend.'
b. Ez dut lagun-ika-n. dialectal, areas of central Basque

The distribution of the partitive DP is identical in both cases (the (b) instance keeps the final vowel lost in word-final position in (a)). That the $-a$ - there is part of the partitive suffix and not the $-a$ of inessives is shown by the fact that it does not trigger epenthesis:
(124) *Ez dut
lagun-ik-e-a-n.
not AUX[1sE-3sA] friend-PART-EPENTH-D-INESS
'I don't have any friend.'

In both $(123 \mathrm{a}, \mathrm{b})$ the complement of the verb have behaves as a nominal argument, requiring the presence of a transitive auxiliary, and showing sensitivity to non-veridical contexts (Etxepare 2003). This clearly indicates that the head of the nominal complement is the partitive Determiner, despite the fact that the inessive comes last. In my analysis, the inessive is just part of the inner functional structure of a clause-like adpositional phrase, which is merged to the partitive determiner -rika. TPs headed by -rik(a), included clausal nominalizations, have the distribution of DPs.

$$
\begin{aligned}
& \text { Ez dut nahi [ hori eroste-rika(n)]. } \\
& \text { not AUx[1sE-3sA] want that-ABS buy-NOM-PART } \\
& \text { 'I don't want for [someone/you to buy that].' }
\end{aligned}
$$

The presence of the inner inessive suggests the presence of a silent nominal. It cannot involve location, though, since the meaning of the whole is not locative. In this regard, this case is akin to non-locative there (Kayne 2005), as in the relatively unproductive English (126):

(126) Jon spoke thereof.

Kayne convincingly argues that an abstract THING underlies the uses of nonlocative there. If this is the case, the structure of (123b) must involve a silent THING. Capitalizing on Ortiz de Urbina's (1989) analysis of the partitive as a 
binominal construction including a silent quantifier, I suggest the following rough underlying structure for those cases:

$$
\left[_{\mathrm{QP}-} \text { rika }\left[_{\text {InessP }}-\mathrm{n}[\mathrm{SC} \text { lagun } \mathrm{THING}]\right]\right]
$$

The silent THING raises to the Spec of the Inessive Phrase and the NP is licensed in the Spec of the quantificational projection.

The partitive determiner is incompatible with number. This suggests the following generalization for Basque abstract nouns PLACE, PERSON and THING:

(128) Basque abstract nouns are incompatible with number.

\section{Summary}

The present paper approaches the structure of Basque adpositional phrases from a perspective that stresses their parallelism with clausal structures. It derives some classical asymmetries in the morphosyntax of Basque primary adpositions by exploring the possibility that those asymmetries may involve functional properties and licensing relations which are operative and well attested at the clausal level: generalizations concerning case-licensing, basic functional sequences which recall those found at the clausal level, or agreement restrictions which seem to affect in a parallel fashion selected syntactic categories (such as anaphors) in both CPs and adpositional phrases.

The paper contributes a detailed analysis of the internal syntactic configuration of basic adpositional structures in Basque by delimiting the respective contributions of primary adpositions, locational nouns, spatial grounds and abstract silent nominals to the overall syntax of locative constructions. It postulates the existence of abstract nouns in those constructions, such as PLACE, PERSON or THING, whose contribution can be indirectly detected in the morphosyntactic behavior of adpositional phrases. Many of the case stacking phenomena in Basque locative phrases are related to the underlying presence of such nouns. This line of analysis meets some of the recent theoretical work focusing on the internal structure of locative PPs and demonstratives.

One important conclusion of the analysis defended here is that much of the morphology which appears to be directly related to the expression of spatial concepts must be reanalyzed as obeying a more formal role, that of licensing syntactically substantive elements which are at the basis of the spatial interpretation of the relevant structures. This is particularly clear when we see that the relevant structure may be involved in concepts which are not spatial at all, but require the same sort of syntactic licensing, as the structures involving an abstract THING. Two prominent affixes have been shown to contribute to this syntactic licensing: one is the Basque animate affix - $g a$ - , surfacing as $-a$ - in non-animate locative constructions and historically related to the ergative case-suffix $-k$. This affix is involved in the licensing of spatial grounds or axial parts, as they participate in binominal 
constructions. Another one is - $n$-, involved in the licensing of abstract nouns such as PLACE or THING.

The paper contributes a novel analysis of much of the internal syntax of adpositional phrases in Basque, and intends to be a valid reference for comparative work on this issue.

\section{References}

Aboh, Enoch O. (2010). «The P route». In: Cinque, Guglielmo; Rizzi, Luigi (eds.), pp. 225-260.

Arteatx, Iñigo; Artiagoitia, Xabier; Elordieta, Arantzazu (eds.). (2008). Antisimetriaren hipotesia vs. Buru parametroa: euskararen oinarrizko hitz hurrenkera ezbaian. Bilbao: University of the Basque Country.

Artiagoitia, Xabier (1995). «Verbal projections in Basque and minimal structure». ASJU 28.2: $341-504$.

Artiagoitia, Xabier (1998). «Determinatzaile sintagmaren hipotesia euskal gramatikan»'. Uztaro 27: 33-61.

Artiagoitia, Xabier (2004). «Izen sintagmaren birziklatzea: IS-tik izenaren inguruko funtzio buruetara». In: Albizu, Pablo; Fernández, Beatriz (eds.). Euskal Gramatika XXI. mendearen atarian: arazo zaharrak, azterbide berriak. Vitoria-Gasteiz: Arabako Foru Aldundia eta Euskal Herriko Unibertsitatea, pp. 11-38.

Artiagoitia, Xabier (2012a). «The DP-hypothesis in the grammar of Basque». In: Etxeberria, Urtzi; Etxepare, Ricardo; Uribe-Etxebarria, Myriam (eds.), pp. 21-78.

Artiagoitia, Xabier (2012b). «Genitive case and multiple checking in Basque». In: Etxeberria, Urtzi; Etxepare, Ricardo; Uribe-Etxebarria, Myriam (eds.), pp. 209-242.

Asbury, Anna; Dotlacil, Jakub; Gehrke, Berit; Nouwen, Rick (eds.) (2008). Syntax and semantics of spatial P. Amsterdam: John Benjamins.

Aurnague, Michel (1996). «Les noms de localisation interne: tentative de caracterisation sémantique à partir des données du basque et du français». Cahiers de lexicologie 69: 159-192.

Aurnague, Michel (2001). Entités et relations dans les descriptions spatiales: l'espace et son expression en basque et en français. Université de Toulouse-Le Mirail, mémoire d'habilitation.

Baker, Mark (1985). «The Mirror Principle and morphosyntactic explanation». Linguistic Inquiry 16: 373-415.

Baker, Mark (2008). The Syntax of Agreement and Concord. Cambridge: CUP.

Bittner, Maria; Hale, Ken (1996). «The structural determination of Case and Agreement». Linguistic Inquiry 27: 1-68.

Borer, Hagit (2005). Structuring sense. Volume I: In name only. Oxford: OUP

Boskovic, Zejlko (1995). The syntax of non-finite complementation. Cambridge, MA: MIT Press.

Bottwinik-Rotten, Irene (2004). The category P. Features, projections, interpretation. University of Tel-Aviv, doctoral dissertation.

Cantrall, William (1974). Viewpoint, Reflexives and the Nature of Noun Phrases. The Hague: Mouton. 
Caha, Pavel (2009). The nanosyntax of case. University of Tromso, doctoral dissertation.

Cattaneo, Andrea (2009). It's all about clitics. The case of a northern Italian dialect like Bellinzonese. New York University, doctoral dissertation.

Cinque, Guglielmo; Rizzi, Luigi (eds.) (2010). Mapping spatial PPs. Oxford: OUP.

Chomsky, Noam (1986). Knowledge of Language. Its Nature, Origin and Use. New York: Praeger.

Chomsky, Noam (2000). New horizons in the study of language and mind. Cambridge: CUP.

Collins, Chris (2007). «Home sweet home». NYU Working Papers in Linguistics 1: $1-34$.

Comrie, Bernard; Polinsky, María (1998). «The great Daghestanian case hoax». In: Siewirska, Anna; Song, Jung-Jae (eds.). Case, typology and grammar. Typological Studies in Language 38. Amsterdam: John Benjamins, pp. 95-114.

Creissels, Denis (2009). «Spatial cases». In: Malchukov, Andrei; Spencer, Andrew (eds), pp. 609-625.

Demirdache, Hamida; Uribe-Etxebarria, Myriam (2000). «The primitives of temporal relations». In: Martin, Roger; Michaels, David; Uriagereka, Juan (eds.). Step by step: Essays in honour of Howard Lasnik. Cambridge, MA: MIT Press, pp. 157-186.

Dikken, Marcel den (2010). «On the functional structure of locative and directional PPs». In: Cinque, Guglielmo; Rizzi, Luigi (eds.), pp. 74-126.

Elordieta, Gorka (1997a). Morphosyntactic feature chains and phonological domains. University of Southern California, doctoral dissertation.

Elordieta, Gorka (1997b). «Feature licensing, morphological words, and phonological domains in Basque». In: Mendikoetxea, Amaia; Uribe-Etxebarria, Myriam (eds.). Theoretical issues at the morphology-syntax interface. Supplements of ASJU. Donostia: University of the Basque Country and Gipuzkoako Foru Aldundia, pp. 171-202.

Etxegorri, Philippe (2013). Biarnoko Euskaldunak. Zingi-Zango Legazpiko Euskara Elkartea/Eusko Jaurlaritza.

Etxeberria, Urtzi (2005). Quantification and domain restriction in Basque. University of the Basque Country, doctoral dissertation.

Etxeberria, Urtzi (2011). «From a Basque with bare nouns to a Basque without». Handout of Basque Comparative Syntax Seminar, Bilbao.

Etxeberria, Urtzi; Etxepare, Ricardo (2012). «Number agreement in Basque: Counting vs. measurig». In: Etxeberria, Urtzi; Etxepare, Ricardo; Uribe-Etxeberria, Myriam (eds.), pp. 149-178.

Etxeberria, Urtzi; Etxepare, Ricardo; Uribe-Etxebarria, Myriam (eds.) (2012). Noun phrases and nominalizations in Basque. Amsterdam: John Benjamins.

Etxepare, Ricardo (2003). «Negation». In: Hualde, José Ignacio; Ortiz de Urbina, Jon (eds.), pp. 516-564.

Etxepare, Ricardo (in press). «Basque spatial cases and the ergative-absolutive syncretism». In: Gómez, Ricardo; Gorrochategui, Joaquín; Lakarra, Joseba Andoni; Mounole, Celine (eds.). 3rd Conference of the Luis Michelena Chair - Koldo Mitxelena Katedraren III. Biltzarra - III Congreso de la Cátedra Luis Michelena ('Koldo Mitxelena' Katedraren Argitalpenak, 5). Vitoria-Gasteiz: UPV/EHUren Argitalpen Zerbitzua. 
Etxepare, Ricardo; Oyharçabal, Bernard (2013). «Datives and adpositions in NorthEastern Basque». In: Etxepare, Ricardo; Fernández, Beatriz (eds.). Variation in datives. A microcomparative perspective. Oxford: OUP, pp. 50-95.

Etxepare, Ricardo; Uribe-Etxebarria, Myriam (2009). «Hitz hurrenkera eta birregituraketa euskaraz». In: Etxepare, Ricardo; Gómez, Ricardo; Lakarra, Joseba Andoni (eds.). A Festshcrift for Bernard Oyharçabal. ASJU 43-1/2: 335-356.

Eguzkitza, Andoni (1997). «Postposizioak euskal gramatikan». In: Túrrez, Itziar; Arejita, Adolfo; Isasi, Carmen (eds.). Studia Philologica in Honorem Alfonso Irigoien. Bilbao: University of Deusto, pp. 83-88.

Euskaltzaindia (1985). Euskal Gramatika. Lehen Urratsak I. Nafarroa: Nafarroako Foru Elkargoa eta Euskaltzaindia.

Fábregas, Antonio (2007). «(Axial) parts and wholes». In: Basic, Mónica; Pantcheva, Marina (eds.). Special issue on space, motion and result. Nordlyd 34.2: 1-32.

Haddican, William (2001). «Basque functional heads». Linguistics in the Big Apple. CUNY/NYU Working Papers in Linguistics.

Hualde, José Ignacio (2002). «Regarding Basque postpositions and related matters». In: Artiagoitia, Xabier; Goenaga, Patxi; Lakarra, Joseba Andoni (eds.). Erramu Boneta. Festschrift for Rudolf P.G. De Rijk. ASJU Supplements 44. Bilbao: University of the Basque Country, pp. 325-340.

Hualde, José Ignacio (2003). «Case and number inflection of Noun Phrases». In: Hualde, José Ignacio; Ortiz de Urbina, Jon (eds.), pp. 171-179.

Hualde, José Ignacio; Ortiz de Urbina, Jon (eds.) (2003). A Grammar of Basque. Berlin: Mouton de Gruyter.

Hualde, José Ignacio (1993). «Topics in Souletin phonology». In: Hualde, José Ignacio and Ortiz de Urbina, Jon (eds.). Generative studies in Basque linguistics. Amsterdam: John Benjamins, pp. 289-327.

Ibarretxe-Antuñano, Iraide (2004). «Polysemy in Basque locational cases». Belgian Journal of Linguistics 18: 271-298.

Jacobsen, William H. (1977). «The Basque locative suffix». In: Douglass, William; Etulain, Richard W.; Jacobsen, William H. (eds.). Anglo-American contributions to Basque studies: Essays in honor of Jon Bilbao. Reno: Desert Research Institute Publications on the Social Sciences no 13, pp. 163-168.

Jackendoff, Ray (1983). Semantics and cognition. Cambridge, MA: MIT Press.

Jackendoff, Ray (1990). Semantic structures. Cambridge, MA: MIT Press.

Jackendoff, Ray (1996). «The architecture of the linguistic-spatial interface». In: Bloom, Paul; Peterson, Mary A.; Nadel, Lynn; Garrett, Merrill F. (eds.). Language and space. Cambridge, MA: MIT Press, pp. 1-30.

Jackendoff, Ray; Landau, Barbara (1992). «Spatial language and spatial cognition». In: Jackendoff, Ray (ed.). Languages of the mind. Essays on mental representation. Cambridge, MA: MIT Press, pp. 99-124.

Johns, Alana (1992). «Deriving ergativity». Linguistic Inquiry 23: 57-87.

Kayne, Richard (1994). The antisymmetry of syntax. Cambridge, MA: MIT Press.

Kayne, Richard (2005). Movement and silence. Oxford: OUP.

Koopman, Hilda (2000). «Prepositions, postpositions, circumpositions and particles». In: Koopman, Hilda (ed.). The syntax of specifiers and heads. London: Routledge, pp. 204-260. 
Kracht, Marcus (2002). «On the semantics of locatives». Linguistics and Philosophy 25: $157-232$.

Laka, Itziar (1993). «Unergatives that assign ergative, unaccusatives that assign accusative». In: Bobaljik, Jonathan; Philips, Collin (eds.). MIT Working Papers in Linguistics 18: Papers on Case and Agreement 1, pp. 149-172.

Lakarra, Joseba (2005). «Prolegómenos a la reconstrucción de segundo grado y al análisis del cambio tipológico en (proto) vasco». Palaeohispánica 5: 407-471.

Leu, Thomas (2008). The internal syntax of determiners. New York University, doctoral dissertation.

Longobardi, Giuseppe (1994). «Reference and proper names: A theory of N-movement in syntax and Logical Form». Linguistic Inquiry 25: 609-665.

Malchukov, Andrei; Spencer, Andrew (eds.). (2009) The Oxford handbook of Case. Oxford: OUP.

Manterola, Julen (2006). «- $a$ euskal artikulu definituaren gainean zenbait ohar». In: Lakarra, Joseba Andoni; Hualde, José Ignacio (eds.). Studies in Basque and historical linguistics in memory of R.L. Trask. Special Issue of the ASJU 40.1/2: 651-676.

Manterola, Julen (2009). «Is Basque an agglutinative language?». In TINTA, Research Journal of Hispanic and Lusophone Studies, University of California Santa Barbara.

Markman, Vita; Graschenkov, Pavel (2012). «On the adpositional nature of ergative subjects». Lingua 122: 257-266.

Martinez Areta, Mikel (2013). «Demonstratives and personal pronouns». In: MartinezAreta, Mikel (ed.). Basque and Proto-Basque. Language internal and typological approaches to linguistic reconstruction. Frankfurt: Peter Lang, pp. 283-321.

Mascaró, Joan (2007). «External allomorphy and lexical representation». Linguistic Inquiry 38: 715-735.

Matushansky, Ora (2008). «On the linguistic complexity of proper nouns». Linguistics and Philosophy 21: 573-627.

Michelena, Luis (1990) [1961]. Fonética histórica vasca. Donostia: University of the Basque Country and Gipuzkoako Foru Aldundia.

Mohanan, Tara (1994). Argument Structure in Hindi. Chicago: University of Chicago Press.

Ortiz de Urbina, Jon (1989). Parameters in the grammar of Basque. Dordrecht: Foris.

Pantcheva, Marina (2008). «The place of PLACE in Persian». In: Asbury, Anna; Dotlacil, Jakub; Gehrke, Berit; Nouwen, Rick (eds.), pp. 305-330.

Pantcheva, Marina (2010). «The syntactic structure of Locations, Goals and Sources». Linguistics 48: 1043-1082.

Pantcheva, Marina (2011). Decomposing Path. The nanosyntax of directional expressions. CASTL. University of Tromso, doctoral dissertation.

Rezac, Milan; Albizu, Pablo; Etxepare, Ricardo (in press). «Structural ergative case». Natural Language and Linguistic Theory.

Rijk, Rudolf De (1981). «Euskal morfologiaren zenbait gora-behera». In: Euskal Linguistika eta Literatura : Bide Berriak. Bilbo: Deustuko Unibertsitatea, pp. 83-102.

Rijk, Rudolf De (1990). «Location nouns in standard Basque». ASJU 24: 3-20.

Rijk, Rudolf De (2008). Standard Basque. Cambridge, MA: MIT Press.

Riemsdijk, van Henk (1978). A case-study in syntactic markedness: The binding nature of prepositional phrases. Dordrecht: Foris. 
Riemsdijk, van Henk; Huijbregts, M.A.C. (2007). «Location and locality». In: Karimi, Simon; Samiian, Vida; Wilkins, Wendy (eds.). Phrasal and clausal architecture. Syntactic derivation and interpretation. In honor of Joseph E. Emonds. Amsterdam: John Benjamins, pp. 339-364.

Rizzi, Luigi (1990). «On the anaphor-agreement effect». Rivista di Linguistica 2: 27-42.

Rooryck, Johann; Vanden Wyngaerd, Guido (2007). «The syntax of spatial anaphora', In: Basic, Monika; Pantcheva, Marina (eds.). Special issue on space, motion and result. Nordlyd 34.2: 33-85.

Salaburu, Pello (1986) «La teoría del ligamiento en la lengua vasca». ASJU 20: 359-412.

San Martin, Itziar (2002). On subordination and the distribution of PRO. University of Maryland, doctoral dissertation.

Santazilia, Ekaitz (2013). «The Noun Phrase / Noun morphology». In: MartinezAreta, Mikel (ed.). Basque and Proto-Basque. Language internal and typological approaches to linguistic reconstruction. Frankfurt: Peter Lang, pp. 223-281.

Son, Minjeong; Svenonius, Peter (2008). «Microparameters of cross-linguistic variation: Directed motion and resultatives». In: Abner, Natasha; Bishop, Jason (eds.). Proceedings of the $27^{\text {th }}$ WCCFL. Sommerville, MA: Cascadilla Proceedings Project, pp. 388-396.

Starke, Michael (2009). «Nanosyntax. A short primer to a new approach to language». In: Svenonius, Peter; Starke, Michael; Taraldsen, Knut. T. (eds.). Special issue on nanosyntax. Norlyd 36-1: 1-6.

Svenonius, Peter (2006). "The emergence of axial parts». In: Svenonius, Peter; Pantcheva, Marina (eds.). Special issue on adpositions. Nordlyd 33-1: 49-77.

Svenonius, Peter (2008). «Projections of P». In: Asbury, Anna; Dotlacil, Jakub; Gehrke, Berit; Nouwen, Rick (eds.), pp. 63-84.

Svenonius, Peter (2010). «Spatial P in English». In: Cinque, Guglielmo; Rizzi, Luigi (eds.), pp.127-160.

Terzi, Arhonto (2010). «Locative prepositions and Place». In: Cinque, Guglielmo; Rizzi, Luigi (eds.), pp. 196-224.

Trask, Larry (2003). «The Noun Phrase: nouns, determiners and modifiers; pronouns and names». In: Hualde, José Ignacio; Ortiz de Urbina, Jon (eds.), pp. 113-170.

Woolford, Ellen (1999). «More on the Anaphor-Agreement Effect». Linguistic Inquiry 30: 257-288.

Zabala, Igone (1993) Predikazioaren teoriak gramatika sortzailean. UPV-EHU, doctoral dissertation. 